\title{
POTENSI EKSTRAK DAUN KERSEN SEBAGAI BAHAN SANITASI KERABANG TELUR PADA PROSES PENETASAN TELUR ITIK ALABIO
}

(The Potential Of Cherry Leaf Extract (Mutinga calabura L) As A Sanitary Agent For Eggshell In The Alabio Ducks Hatching Process)

\author{
Gilang Ayuningtyas ${ }^{1}$, Rina Martini ${ }^{2}$, Wina Yulianti ${ }^{3}$ \\ ${ }^{1}$ Program Studi Teknologi dan Manajemen Ternak, Sekolah Vokasi IPB \\ 2 Program Studi Manajemen Industri Jasa Makanan dan Gizi., Sekolah Vokasi IPB \\ ${ }^{3}$ Program Studi Analisis Kimia, Sekolah Vokasi, Institut Pertaninan Bogor
}

E-mail : gilang_a@apps.ipb.ac.id

\begin{abstract}
The research aimed is to study the potential of cherry leaf extract as a natural sanitizer agent for Alabio eggshell in the hatching process. A number of 533 of Alabio hatching eggs were used in this study. Hatching eggs produced from College of Vocational Studies IPB University; were collected three times a day. Three hundred thirty-three hatching eggs were divided into five treatment groups. The first group was considered as control, the second was dipping into commercial disinfection, and the third and the fifth group were dipping into cherry leaf extract 250 ppm, 500 ppm, and 750 ppm, respectively. The results showed cherry leaf extract has secondary metabolite compounds : alkaloids, flavonoids, and tannins. All of these secondary metabolite compounds have a role as an antibacterial agents. Cherry leaf extract $750 \mathrm{ppm}$ shows the same potential as commercial disinfectants as a sanitizing agent for alabio duck egg-shells. The dipping treatment of 750 ppm cherry leaf extract in alabio duck hatching eggs resulted in the lowest embryo mortality rate compared to other treatments $(9,3 \%)$.
\end{abstract}

Key words : Alabio duck, cherry leaf extract, hatchery, total plate count of eggshell 


\section{PENDAHULUAN}

Kebersihan telur tetas merupakan salah satu kunci keberhasilan proses penetasan telur unggas. Upaya untuk menghasilkan telur tetas unggas yang bersih secara fisik dan mikrobiologis dilakukan mulai dari proses budidaya unggas pembibit di dalam kandang, melalui penyediaan nest box / sarang bertelur, pengkoleksian telur tetas dilakukan sesering mungkin (4-7 kali per hari), menyimpan telur tetas pada egg tray yang bersih, dan melakukan pembersihan fisik pada telur-telur tetas yang kotor (Ernst, 2004). Upaya tersebut belum menjamin hilangnya mikroorganisme pada permukaan kerabang telur tetas atau bahkan yang sudah berpenetrasi ke bagian interior telur. Proses fumigasi menggunakan gas formaldehid telah lama diaplikasikan untuk mengurangi dan menghilangkan kontaminasi mikroorganisme pada permukaan kerabang telur, sebelum telur tesebut ditetaskan menggunakan mesin tetas. Namun demikian gas formaldehid yang terbuat dari reaksi formalin dan kalium permanganate (KMNO4) merupakan gas yang berbahaya baik bagi bakal embrio maupun manusia sebagai operator proses penetasan. Bahaya yang dapat ditimbulkan formalin bagi manusia diantaranya menyebabkan iritasi, bersifat karsinogenik, dan mutagenik. KMnO4 saat ini tidak sembarangan diperjualbelikan, karena bahan kimia ini sering disalahgunakan untuk dijadikan bahan peledak.

Berdasarkan kondisi-kondisi diatas, perlu diteliti alternatif bahan untuk proses sanitasi telur tetas itik sebagai pengganti proses fumigasi gas formaldehid. Bahan sanitasi (sanitizer) tersebut haruslah aman baik bagi calon embrio telur dan juga manusia sebagai operator penetasan, serta ramah terhadap lingkungan. Bahan kimia yang berasal dari alam, seperti yang terkandung pada beberapa tanaman di Indonesia, diketahui memiliki aktifitas antibakteri dengan spektrum yang cukup luas, seperti pada daun tanaman kersen, sirih hijau, dan sirih merah.

Daun kersen (Muntingia calabura) memiliki beberapa kandungan senyawa aktif yang mampu bekerja sebagai antibakteri. Flavonoid, saponin dan tanin terkandung dalam daun kersen bersifat antibakteri (Kurniawan et al., 2013). Hal ini sejalan dengan penelitian Buhian et al.. (2016), hasil skrining komponen fitokimia pada ekstrak etanol daun kersen terkandung metabolit sekunder yaitu: sterol, triterpenoid, flavonoid, alkaloid, saponin, glikosida, dan tanin. Flavonoid dan saponin memiliki intensitas kepekatan yang lebih dibandingkan senyawa lainnya. Hasil uji aktivitas antibakteri ekstrak etanol 70\% daun kersen memperlihatkan aktivitas antibakteri terhadap Bacillus subtilis dan Shigella dysenteriae, dengan konsentrasi Bunuh Minimum (KBM) terhadap bakteri Bacillus subtilis sebesar $6,25 \%$ dan Shigella dysenteriae sebesar 3,25\% (Prasetyo dan Sasongko, 2014). Ekstrak etonol daun kersen juga diketahui memiliki aktivitas antibakteri terhadap bakteri E. Coli, P. aeruginosa, S. typhimurium, S. aureus, B. Subtilis, dan C. albicansi dan diameter zona hambat tertinggi ditunjukkan pada bakteri $S$. aureus (Buhian 2016).

Keberadaan daun kersen belum termanfaatkan secara penuh dan kurang memiliki nilai ekonomi. Beberapa penelitian telah dilakukan untuk memanfaatkan 
daun kersen sebagai bahan antiseptik di bidang peternakan diantaranya sebagai antiseptik pada proses perendaman puting sapi perah (Prasetyanti, 2016) dan ekstrak daun kersen sebagai bahan sanitasi kerabang telur tetas itik hibrida (Alhakim, 2016). Hasil penelitian Alhakim (2016), ekstrak etanol daun kersen $20 \%$ menunjukkan hasil yang signifikan dalam menekan mortalitas embrio dan meningkatkan daya tetas pada proses penetasan telur itik hibrida. Namun demikian penelitian mengenai aplikasi ekstrak pekat daun kersen sebagai bahan sanitasi telur tetas itik Alabio dan mengetahui kemampuannya menekan kontaminasi mikrobiologis pada kerabang telur belum dilakukan. Penelitian ini dilakukan untuk mengkaji potensi ekstrak pekat daun kersen sebagai bahan sanitasi alami pada proses pembersihan kerabang telur tetas itik terhadap kemampuannya mengurangi populasi mikroorganisme pada permukaan kerabang telur itik dan pengaruhnya pada angka mortalitas embrio selama proses penetasan.

\section{METODE PENELITIAN}

\section{Preparasi Sampel (Neto Bandeira et al., 2013)}

Daun kersen yang diperoleh dari Kawasan Sekolah Vokasi IPB dikeringudarakan tanpa kena sinar matahari secara langsung selama 24 jam. Daun kemudian di oven pada suhu $40{ }^{\circ} \mathrm{C}$ selama $3 \times 24$ jam. Daun kersen kemudian yang ditelah dioven kemudian dihaluskan menggunakan blender. Sampel yang sudah diblender digunakan untuk tahapan analisis selanjutnya.

\section{Penentuan Kadar Air (SNI 01-2891-1992)}

Cawan yang kering dan bersih dipanaskan di dalam oven selama \pm 30 menit kemudian didinginkan, dan disimpan di dalam desikator lalu ditimbang. Simplisia daun kersen ditimbang sebanyak 2 gram, dimasukkan ke dalam cawan kemudian dipanaskan di dalam oven dengan suhu $105^{\circ} \mathrm{C}$ selama 5 jam. Cawan kemudian didinginkan, disimpan di dalam desikator dan ditimbang.

\section{Ekstraksi Sampel (Dwi and Syam, 2017)}

Daun kersen ditimbang sebanyak 200 gram kemudian diekstraksi dengan cara maserasi menggunakan dua jenis pelarut pengekstrak, yaitu air dan etanol pa. Rasio perbandingan bobot sampel dan pelarut pengekstrak sebesar 1:16. Maserasi dilakukan selama $3 \times 24$ jam. Ekstrak yang diperoleh dipekatkan menggunakan penguap vakum putar kemudian ditimbang dan ditentukan rendemennya.

\section{Uji Fitokimia (Harborne 1984)}

Uji Kualitatif Alkaloid. Sebanyak 1 sudip sampel dimasukkan ke dalam

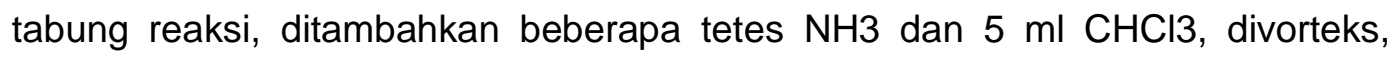
kemudian disaring. Filtrat hasil penyaringan ditambahkan beberapa tetes $\mathrm{H} 2 \mathrm{SO} 4$ $2 \mathrm{M}$ kemudian dikocok sehingga terbentuk dua lapisan. Lapisan bagian atas 
(lapisan asam) dibagi menjadi tiga bagian ke atas pelat tetes kemudian masingmasing ditambahkan pereaksi Dragendorf, Mayer, dan Wagner. Hasil positif alkaloid diamati dengan terbentuknya endapan jingga oleh pereaksi Dragendorf, endapan putih oleh pereaksi Mayer, dan endapan cokelat oleh pereaksi Wagner.

Uji Kualitatif Fenol. Uji ini dilakukan untuk mengetahui adanya flavonoid, tanin, dan saponin pada sampel. Sebanyak 3 sudip sampel ditambahkan dengan $10 \mathrm{~mL}$ akuades kemudian dididihkan selama 5 menit, disaring dan filtratnya dibagi ke dalam 3 tabung reaksi. Tabung reaksi pertama digunakan untuk uji flavonoid. Sebanyak $3 \mathrm{~mL}$ filtrat ditambahkan seujung sudip serbuk $\mathrm{Mg}, 10$ tetes $\mathrm{HCl}$ pekat, 10 tetes etanol dan $1 \mathrm{~mL}$ amil alkohol. Hasil positif flavonoid diamati dengan terbentuknya warna jingga pada lapisan amil alkohol. Tabung reaksi kedua digunakan untuk uji tanin. Sebanyak $2 \mathrm{~mL}$ filtrat ditambahkan 1-3 tetes $\mathrm{FeCl} 3$ 10\% dan hasil positif tanin diamati dengan terbentuknya larutan berwarna hitam kehijauan. Tabung reaksi ketiga digunakan untuk uji saponin. Sebanyak $4 \mathrm{~mL}$ filtrat dikocok kuat dan hasil positif saponin diamati dengan terbentuknya buih stabil selama 30 detik.

Uji Kualitatif Steroid/Triterpenoid. Sebanyak 1 sudip sampel dimasukkan ke dalam tabung reaksi, ditambahkan $5 \mathrm{~mL}$ etanol kemudian dididihkan selama 2 menit dan disaring. Filtrat hasil penyaringan dipanaskan hingga kering. Filtrat yang telah kering tersebut kemudian ditambahkan $1 \mathrm{~mL}$ dietil eter, divorteks, dan dipindahkan ke dalam pinggan porselen. Sebanyak 5 tetes $\mathrm{H} 2 \mathrm{SO} 4$ pekat dan 5 tetes $\mathrm{CH} 3 \mathrm{COOH}$ anhidrat ditambahkan ke dalam pinggan dan diamati warna yang terbentuk. Hasil positif steroid diamati dengan terbentuknya warna hijau-biru dan triterpenoid diam ati dengan terbentuknya warna merah.

\section{Sanitasi Kerabang Telur Tetas Itik}

Telur itik alabio diperoleh dari Laboratorium Lapang Unit Unggas Sekolah Vokasi IPB sebanyak 533 butir dengan umur kurang dari 24 jam setelah ditelurkan. Telur tetas yang telah lolos seleksi akan dikelompokan berdasarkan perlakukan penelitian ditempatkan dalam egg tray yang bersih. Proses sanitasi telur dengan metode perendaman mengacu pada Harikrishnan et al.. (2014), yaitu dengan suhu perendaman air hangat $40{ }^{\circ} \mathrm{C}$ selama 5 menit. Setelah direndam, kemudian diberiskan dari kotoran fisik. Tahap selanjutnya telur ditiriskan sampai kering udara pada egg tray bersih. Telur-telur tersebut kemudian direndam pada masingmasing bahan perlakuan (P2 - P5) selama 5 menit. Telur disimpan kembali pada egg tray bersih dan dibiarkan mengering. Perlakuan penelitian dapat dilihat pada Tabel 1.

Tabel 1 Perlakuan penelitian

\begin{tabular}{cll}
\hline Perlakuan & \multicolumn{1}{c}{ Konsentrasi } & \multicolumn{1}{c}{ Metode } \\
\hline Kontrol air hangat (P1) & Air dengan suhu $40^{\circ} \mathrm{C}$ & Perendaman \\
Desinfektan kimia (P2) & $0,15 \%(1.5 \mathrm{ml}$ dalam 1 liter air) & Perendaman
\end{tabular}




\begin{tabular}{|c|c|c|}
\hline Perlakuan & Konsentrasi & Metode \\
\hline Ekstrak Pekat Daun Kersen (P3) & $\begin{array}{l}250 \text { ppm }(50 \mathrm{ml} \text { ekstrak daun } \\
\text { kersen } 5000 \text { ppm, } 950 \mathrm{ml} \\
\text { Aquabides) }\end{array}$ & Perendaman \\
\hline Ekstrak Pekat Daun Kersen (P4) & $\begin{array}{l}500 \text { ppm (100 ml ekstrak daun } \\
\text { kersen } 5000 \text { ppm, } 900 \mathrm{ml} \\
\text { Aquabides) }\end{array}$ & Perendaman \\
\hline Ekstrak Pekat Daun Kersen (P5) & $\begin{array}{l}750 \text { ppm (150 ml ekstrak daun } \\
\text { kersen } 5000 \text { ppm, } 850 \mathrm{ml} \\
\text { Aquabides) }\end{array}$ & Perendaman \\
\hline
\end{tabular}

Keterangan : Perlakuan per 1 liter

\section{Pengujian Kualitas Mikrobiologi Kerabang Telur (DSN, 1992)}

Metode Pengujian kualitas mikrobiologi telur dengan metode total plate count (TPC) Dewan Standardisasi Nasional (DSN, 1992) dimodifikasi:

Swab kerabang telur. Kerabang telur itik yang telah dibersihkan oleh larutan perlakuan kemudian di swab dengan area $2 \times 2 \mathrm{~cm}$ menggunakan cotton swab yang steril. Cotton swab yang telah diswab pada kerabang telur kemudian dimasukkan ke dalam tabung reaksi yang berisi $10 \mathrm{ml}$ BPW, selanjutnya sebanyak $1 \mathrm{ml}$ dimasukkan ke dalam tabung reaksi berisi $9 \mathrm{ml}$ larutan BPW. Campuran dihomogenkan dan didapatkan pengenceran satu per sepuluh (PI). Pemupukan dilakukan terhadap semua pengenceran yang telah dilakukan (PI) dengan cara 1 $\mathrm{ml}$ pengenceran dipipet ke dalam cawan petri secara duplo dan ditambahkan medium agar PCA sebanyak 15-20 ml. Campuran dihomogenkan dengan cara digerakkan membentuk angka delapan diatas bidang datar dan dibiarkan hingga agar-agar mengeras. Cawan petri selanjutnya di tutup dengan plastik warm dan diinkubasi pada suhu $37^{\circ} \mathrm{C}$ dengan posisi terbalik selama 24 jam.

Penghitungan koloni. Penghitungan koloni yang tumbuh dilakukan setelah inkubasi 24 jam, menggunakan colony counter. Cara penghitungan jumlah koloni adalah :

Jumlah bakteri $=$ rata-rata jumlah koloni $\times 1$ faktor pengenceran/cm2 $\times$ luasan telur

\section{Penetasan Telur Itik dan Mortalitas Embrio}

Proses penetasan menggunakan mesin tetas otomatis berkapasitas masingmasing 1000 butir baik pada mesin setter (pengeram) maupun mesin hatcher (penetas). Sebelum digunakan mesin dibersikan menggunakan detergen, didesinfeksi, lalu difumigasi menggunakan formalin dan KMNO4. Suhu dan kelembaban mesin tetas diatur pada $37-38{ }^{\circ} \mathrm{C}$ dan $60-70 \%$. Telur yang akan ditetaskan, diberi identitas nomor telur pada kerabangnya. Pemutaran telur dilakukan pada hari ke 3 pengeraman hingga hari ke-25. Pemutaran telur dilakukan secara otomatis setiap satu jam dengan membentuk sudut kemiringan $45^{\circ}$. Pendinginan terhadap telur tetas dilakukan mulai hari ke-17 sampai hari ke25 sebanyak 2 kali sehari (pagi dan sore) masing-masing selama 15 menit. 
Frekuensi pendinginan ditingkatkan menjadi 3 kali sehari (pagi, sore dan malam hari) pada hari ke-26 hingga hari ke-28 (menetas). Telur tetas dilakukan peneropongan (candling) pada hari ke 7 dan 25 untuk melihat kondisi dan perkembangan embrio selama proses penetasan. Candling hari ke-7 untuk menentukan telur fertil, infertile, atau fertil mati (dini/early death).

Telur infertile dan mati dikeluarkan dari mesin tetas. Candling pada hari ke25 atau pada saat transfer telur dilakukan untuk melihat kondisi embrio hidup ataukah mati. Embrio yang hidup akan dipindahkan ke mesin hatcher/penetas (proses transfer telur). Proses penetasan pada mesin hatcher berlangsung hingga hari ke-28. Akhir proses penetasan dilakukan dilakukan analisis kematian/ mortalitas embrio. Persentase mortalitas berdasarkan persentase telur fertil dengan rumus sebagai berikut.

Mortalitas embrio (\%) $=($ Jumlah embrio mati $) /($ Jumlah telur fertil $) \times 100 \%$

\section{Analisis Statistik}

Analisis statistik dilakukan menggunakan software Minitab 17 dengan model rancangan percobaan adalah :

$$
Y i j=\mu+T i+b j+\epsilon i
$$

Keterangan :

$Y_{\mathrm{ij}}$ : nilai pengamatan dari perlakuan ke-i dalam kelompok ke-j

$\mu$ : nilai tengah

$\mathrm{T}_{i}$ : pengaruh aditif dari perlakuan ke-i

$b_{j}$ : pengaruh aditif dari ulangan ke-j

$\epsilon_{\mathrm{ij}}$ : pengaruh galat percobaan dari perlakuan ke-i pada kelompok ke-j

Uji lanjut dengan uji jarak berganda TUKEY HSD untuk mengetahui perbedaan antar perlakuan.

\section{HASIL DAN PEMBAHASAN}

\section{Kadar Air}

Daun kersen yang digunakan dalam analisis mengandung kadar air yang rendah yaitu 9,18\%. Kadar air merupakan banyaknya air yang terkandung dalam bahan yang dinyatakan dalam persen. Kadar air yang tinggi mengakibatkan mudahnya bakteri, kapang, dan khamir untuk berkembang biak. Sampel dengan kadar air yang tinggi akan lebih mudah tercemar oleh jamur dan mikroba.

\section{Uji Fitokimia}

Uji fitokimia dilakukan untuk mengetahui kandungan zat kimia yang terdapat pada ekstrak daun kersen. Hasil uji fitokimia ekstrak etanol daun kersen menunjukan bahwa ekstrak mengandung alkaloid, flavonoid dan tanin (Tabel 2) dan intensitas kepekatan tanin lebih pekat dibandingkan senyawa alkaloid dan flavonoid. 
Tabel 2 Kandungan senyawa metabolit sekunder ekstrak etanol daun kersen

\begin{tabular}{llc}
\hline \multicolumn{1}{c}{ Metabolit sekunder } & Warna yang terbentuk & Intensitas \\
\hline Alkaloid & Endapan coklat & + \\
Tanin & Hijau pekat & +++ \\
Flavonoid & Jingga & ++ \\
\hline
\end{tabular}

Berdasarkan Fariestha GA et al. (2018), senyawa metabolit daun kersen mengandung flavonoids, tannins, saponins, alkaloids and triterpenoids. Kandungan metabolit sekunder flavonoid dapat menghambat pertumbuhan bakteri. Daun kersen yang diekstrak dengan pelarut etanol menunjukan aktivitas anti bakteri $P$. aeruginosa and $S$. aureus dengan kandungan metabolit sekunder sterols, flavonoids, alkaloids, saponins, glycosides and tannins (Buhian WPC et al., 2016). Menurut (Juariah et al., 2020) Ekstrak etanol daun kersen dapat dijadikan sebagai alternative penghambat pertumbuhan bakteri.

\section{Kualitas mikrobiologis kerabang telur (total plate count)}

Hasil yang diperoleh dari penelitian ini berupa penghitungan total cemaran mikroba dari kerabang telur yang telah dibersihkan dengan ektrak kersen dalam berbagai konsentrasi (250 ppm, 500 ppm dan 750 ppm). Penghitungan total mikroba dapat dilihat dari Tabel 3 .

Tabel 3 Jumlah cemaran mikroba pada kerabang telur yang telah dibersihkan dengan beberapa perlakuan

\begin{tabular}{clr}
\hline \multirow{2}{*}{ No } & \multicolumn{1}{c}{ Perlakuan } & $\begin{array}{c}\text { Jumlah cemaran mikroba } \\
\text { Log 10 (cfu/egg) }\end{array}$ \\
\hline 1 & P1 (air hangat) & $4,19^{\mathrm{ab}}$ \\
2 & P2 (desinfektan komersial) & $2,59^{\mathrm{b}}$ \\
3 & P3 (ekstrak kersen 250 ppm) & $4,47^{\mathrm{a}}$ \\
4 & P4 (ekstrak kersen 500 ppm) & $4,03^{\mathrm{ab}}$ \\
5 & P5 (ekstrak kersen 750 ppm) & $2,97^{\mathrm{b}}$ \\
\hline \multicolumn{4}{c}{${ }^{*}$ Analysis of Variance dilanjutkan dengan uji Tukey HSD } \\
\end{tabular}

Pada Tabel 3 dapat dilihat bahwa jumlah cemaran mikroba yang paling sedikit terdapat pada kerabang telur yang dibersihkan dengan desinfektan komersial yaitu sebanyak 2,59 log10 (cfu/egg) dan tidak berbeda nyata dengan jumlah cemaran mikroba pada kerabang telur yang dibersihkan dengan ekstrak kersen dengan konsentrasi 750 ppm (2,97 log $10 \mathrm{cfu} / \mathrm{egg}$ ). Total cemaran mikroba dengan prosedur sanitasi menggunakan air hangat, ekstrak kersen 250 ppm dan ekstrak kersen 500 ppm menunjukkan hasil berturut turut : 4,19 log 10 (cfu/egg) ; 4,47 log10 (cfu/egg) dan 4,03 log10 (cfu/egg).

Dari hasil ini dapat dilihat bahwa ekstrak daun kersen dengan konsentrasi 750 ppm mempunyai potensi yang sama dengan desinfektan kimia komersial sebagai bahan sanitasi kerabang telur tetas itik alabio. Penelitian ini sejalan 
dengan beberapa penelitian sebelumnya yang menunjukkan bahwa ekstrak kersen mempunyai sifat sebagai anti bakteri, yaitu pada penelitian Prasetyo dan Sasongko (2014) hasil uji aktivitas antibakteri ekstrak etanol 70\% daun kersen (Muntingia calabura L.) menunjukkan bahwa ekstrak etanol $70 \%$ daun kersen (Muntingia calabura L.) memperlihatkan aktivitas antibakteri terhadap Bacillus subtilis dan Shigella dysenteriae. Konsentrasi Bunuh Minimum (KBM) ekstrak etanol $70 \%$ daun kersen terhadap bakteri Bacillus subtilis sebesar $6.25 \%$ dan Shigella dysenteriae sebesar 3.25\%. Penelitian dari Zakarian et al. (2006) juga menyimpulkan bahwa ekstrak daun kersen memiliki potensi sebagai agen antibakteri dibandingkan dengan penggunaan antibiotik.

Menurut Coufal et al., 2003 dan Zeweil et al., 2015, total aerobic bakteri mesophilic pada kerabang telur ayam yang belum dibersihkan terdapat dalam kisaran 3.75 sampai 7.07 log10 colony-forming units (CFUs) per telur. Apabila dihubungkan dengan penelitian ini maka dapat dilihat bahwa ekstrak kersen pada konsentrasi 750 ppm mampu mereduksi jumlah cemaran mikroba yang terdapat pada kerabang telur (sampai 2,97 log10 cfu/telur). Hal ini akan sangat penting dalam proses sanitasi kerabang telur karena melakukan proses sanitasi pada kerabang telur dengan menggunakan prosedur desinfeksi perlu dilakukan karena akan meningkatkan kualitas telur yang akan diinkubasi dan menurunkan kejadian infeksi bakteri pada tahap embrio dan neonatal (Fasenko et al., 2009).

Penggunaan desinfeksi alami telah banyak dilakukan antara lain oleh Shahein dan Sedeek (2014) desinfeksi secara spraying dengan menggunakan propolis $14 \%$ pada kerabang telur dapat mengurangi total mikroba pada kerabang sampai $17.11 \pm 1.09 \times 103 \mathrm{cfu} /$ telur. Apabila dibandingkan dengan hasil penelitian ini maka ekstrak kersen 750 ppm menghasilkan jumlah total mikroba yang lebih sedikit dibandingkan dengan pemakaian propolis $14 \%$.

\section{Fertilitas dan Mortalitas Embrio}

Fertilitas diartikan sebagai persentase telur-telur yang memperlihatkan adanya perkembangan embrio dari sejumlah telur ditetaskan tanpa memperhatikan telur tersebut menetas atau tidak (Sinabutar, 2009). Berdasarkan data pada Tabel 4 fertilitas telur tetas itik alabio terendah $92.29 \%$ dan tertinggi $95.92 \%$. Fertilitas telur itik alabio yang digunakan pada penelitian ini sejalan dengan hasil penelitian Darmawati et al. (2016) menunjukkan fertilitas telur tetas itik Alabio adalah sebesar 95.67 dan hasil penelitian yang dilakukan oleh Matitaputty (2012) sebesar 95.61\%. Fertilitas dipengaruhi beberapa faktor diantaranya sistem pemeliharaan itik pembibit, sex ratio, metode perkawinan, nutrisi pakan induk, dan kesehatan dari itik pembibit.

Tabel 4 Fertilitas dan mortalitas embrio penetasan telur itik alabio

\begin{tabular}{ccrrr}
\hline Perlakuan & Jumlah (butir) & $\begin{array}{c}\text { Rataan Bobot telur } \\
\text { (g/butir) }\end{array}$ & Fertilitas (\%) & Mortalitas (\%) \\
\hline P1 & 106 & 72,70 & 94,89 & 23,40 \\
P2 & 106 & 70,90 & 95,92 & 17,56 \\
P3 & 107 & 72,00 & 92,38 & 13,90
\end{tabular}




\begin{tabular}{rrrrr}
\hline P4 & 106 & 71,00 & 92,29 & 11,14 \\
P5 & 108 & 73,30 & 94,70 & 9,30 \\
\hline
\end{tabular}

Keterangan : P-value $\geq 0$; tidak signifikan

Hasil sidik ragam terhadap tingkat kematian (mortalitas) embrio itik alabio yang diberi perlakuan menunjukkan tidak siginifikan, namun demikian rataan mortalitas embrio pada telur yang diberi perlakuan ekstrak kersen 750 ppm (P5) memiliki rataan terendah dibandingkan dengan perlakuan lainnya. Hasil ini sejalan dengan penelitian Al Hakim et al. (2016), yaitu ekstrak daun kersen $20 \%$ yang digunakan pada proses sanitasi telur tetas itik memiliki angka mortalitas embrio terendah (12,26\%). Penelitian perendaman sanitasi alami lainnya juga menunjukkan hal yang sama, yaitu telur yang dicelupkan dalam ekstrak daun sirih $10 \%$ memiliki angka motalitas embrio lebih rendah dibandingkan perlakukan lainnya (Nandhra et al., 2015) dan ekstrak Propolis 14\% juga efektif menurunkan angka mortalitas embrio unggas (Shahein, 2014).

Ekstrak daun kersen berdasarakan hasil uji fitokimia menunjukan bahwa ekstrak mengandung alkaloid, flavonoid dan tanin. Tanin memiliki aktivitas antibakteri. Menurut Nurwanto et al. (2004), mekanisme antibakteri tannin antara lain menghambat enzim ektraseluler mikroba, mengambil alih substrat yang dibutuhkan pada pertumbuhan mikroba, atau bekerja langsung pada metabolisme dengan cara menghambat proses oksidasi, sehingga keluarnya air dan gas-gas dalam telur dapat dicegah. Senyawa flavonoid berperan sebagai antioksidan dan antiseptik, dalam beberapa kasus flavonoid dapat berperan secara langsung sebagai antibiotik dengan mengganggu fungsi dari mikroorganisme seperti bakteri atau virus (Hermiati et al., 2013). Selain itu ada juga senyawa alkaloid yang dihasilkan oleh tumbuhan sebagai bagian dari sistem pertahanan diri. Senyawa tersebut berperan sebagai pelindung dari serangan infeksi mikroba patogen (Nandhra et al., 2015).

Telur tetas itik yang hanya direndam dengan air hangat $(\mathrm{P} 1)$ memiliki rataan mortalitas tertinggi yaitu $23,4 \%$. Hasil ini mengindikasikan bahwa proses sanitasi kerabang telur belum cukup baik bila hanya dicuci menggunakan air hangat saja. $\mathrm{Hal}$ ini sejalan dengan jumlah cemaran mikroba pada kerabang telurnya yang relatif tinggi dibandingkan perlakuan lainnya (4,19 log $10 \mathrm{cfu} / \mathrm{egg})$ sehingga mikroorganisme dipermukaan kerabang telur masih memiliki potensi untuk berpenetrasi kedalam telur melalui pori-pori dan menyebabkan kontaminasi sehingga embrio mati. Mikroorganisme alami yang ada pada kebarang telur seperti Salmonella sp, Staphylococci sp, dan Escherichia coli, bakteri ini dapat tumbuh dengan optimum pada suhu $37^{\circ} \mathrm{C}$, sehingga perendaman dalam air hangat $40^{\circ} \mathrm{C}$ belum cukup untuk menekan pertumbuhan bahkan membunuh bakteri-bakteri tersebut. Bakteri Salmonella merupakan bakteri fakultatif anaerob yang dapat tumbuh pada kisaran suhu $5-45^{\circ} \mathrm{C}$ dengan suhu optimumnya adalah $35-37^{\circ} \mathrm{C}$ (Rudiyansyah et al., 2015).

Sanitasi kerabang telur dengan menggunakan bahan desinfektan kimia perlu diperhatikan terkait aturan penggunaannya, hal ini karena bahan kimia yang tersebut dapat masuk ke dalam telur melalui pori-pori kerabang. Pengunaan 
desinfektan kimia dengan jenis, dosis, dan pelaksanaan yang tidak tepat justru dapat menyebabkan kematian embrio saat proses penetasan. Hasil penelitian Zeweil et al. (2015) menunjukkan bahwa desinfektan kimia juga mampu menyebabkan lambatnya perkembangan sistem saraf pusat embrio unggas yang sedang berkembang, sehingga dapat menyebabkan terjadinya kecacatan pada anak unggas seperti tingkah laku yang abnormal, tremor, ketidakmampuan untuk berdiri dan berjalan dengan normal. Data pada Tabel 4 menunjukkan bahwa, telur yang disanitasi dengan menggunakan desinfektan kimia memiliki persentase mortalitas embrio yang lebih tinggi dibandingkan perlakuan ekstrak kersen 250 ppm, 500 ppm, dan 750 ppm. Faktor-faktor penyebab terjadinya kematian embrio pada unggas diantaranya: kualitas telur tetas, umur telur tetas, penanganan dan sintasi telur yang tidak tepat, suhu dan kelembaban mesin tetas, selain itu menurut Setiadi (2000) adanya kontaminasi bakteri pada telur tetas dan pertumbuhan embrio yang tidak sempurna juga merupakan penyebab terjadinya mortalitas embrio.

\section{SIMPULAN}

1. Ekstrak daun kersen berdasarakan hasil uji fitokimia menunjukan bahwa ekstrak mengandung senyawa metabolit sekunder alkaloid, flavonoid dan tanin, dan ketiganya dapat berperan sebagai antibakteri

2. Ekstrak daun kersen dengan konsentrasi 750 ppm mempunyai potensi yang sama dengan desinfektan kimia komersial sebagai bahan sanitasi kerabang telur tetas itik alabio.

3. Perlakuan perendaman ekstrak daun kersen $750 \mathrm{ppm}$ pada telur tetas itik alabio, menghasilkan angka mortalitas embrio terendah dibandingkan pada perlakuan lainnya.

\section{DAFTAR PUSTAKA}

Al Hakim FH, MN Huda, GD Fitri, D Ambarwati, dan H Tistiana. 2016. Pengaruh ekstrak daun kersen terhadap daya tetas dan mortalitas telur itik hibrida. Jurnal IImu-IImu Peternakan 26 (2): 8 - 13.

Buihan WPC, Rubio RO, Jr DLV. 2016. Bioactive metabolite profiles and antimicrobial activity of ethanolic extracts from Muntingia calabura L. leaves and stems. Asian Pac J Trop Biomed 2016; 6(8): 682-685

Coufal C.D, Chavez D, Knape KD, Carey, JB. 2003. Evaluation of a method of ultraviolet light sanitation of broiler hatching eggs. Journal of Poultry Science. Vol.82 (754-759).

Dewan Standardisasi Nasional. 1992. Metode Pengujian Cemaran Mikroba, Standar Nasional Indonesia, Jakarta. SNI 01-2897-1992.

Darmawati D, Rukmiasih, dan R Afnan. 2016. Daya Tetas Telur Itik Cihateup dan Alabio. Jurnal Ilmu Produksi dan Teknologi Hasil Peternakan. 4(1) : 257-263.

Dwi, A. and Syam, L. (2017) 'Perbandingan Metode Ekstraksi Maserasi dan Sokletasi Terhadap Kadar Fenolik Total Ekstrak Etanol Daun Kersen (Muntingia Calabura)', Jurnal IImiah Cendekia Eksakta, pp. 1-8. 
Fasenko, G.M.; O'dea Christopher, E.E.; Mcmullen, L.M. Spraying hatching eggs with electrolyzed oxidizing water reduces eggshell microbial load without compromising broiler production parameters. Poultry Science, v.88, p.11211127, 2009.

Fariestha, G. A. K., Andayani, S. and Yanuhar, U. (2018) 'Analysis of The Secondary Metabolite of Kersen Leaf Extracts (Muntingia calabura L.) and Its Potential as Anti-Bacteria to Inhibit Aeromonas hydrophila', Research Journal of Life Science, 5(2), pp. 121-127. doi: 10.21776/ub.rjls.2018.005.02.6.

Harborne J.B. 1987. Metode Fitokimia Penuntun Cara Modern Menganalisis Tumbuhan. Padmawinata K, Soediro I, penerjemah. Bandung : Penerbit ITB. Terjemahan dari : Phytochemical methods.

Harikrishnan S, Narayanankutty K, Binoj C, Anitha P, Arun RU, Prasoon S. 2014. The effect of various sanitizing agents on the microbial and duckling qualities of kuttanad duck eggs. Int J Dev Res. 4(2): 283-285

Hermiati, Rusli., Manalu, N. Y., Sinaga, M. S. 2013. Ekstrak daun sirih hijau dan merah sebagai antioksidan pada minyak kelapa. Jurnal Teknik Kimia USU. 2 (1): 2-7.

Juariah, S., Yolanda, N. and Surya, A. (2020) 'Efektivitas Ekstrak Etanol Daun Kersen terhadap Staphylococcus Aureus dan Salmonella Typhi', Jurnal Endurance: Kajian Ilmiah Problema Kesehatan, 5(2), pp. 338-344.

Matitaputty PR. 2012. Peningkatan produksi karkas dan kualitas daging itik melalui persilangan antara itik Cihateup dengan itik Alabio [disertasi]. Bogor (ID): Institut Pertanian Bogor.

Mattjik AA, Sumertajaya M. 2000. Perancangan percobaan dengan aplikasi SAS dan MINITAB. Jilid 1. Bogor (Indonesia): IPB Press.

Nandhra, IP, E. Sudjarwo, dan AA Hamiyanti. 2015. Pengaruh penggunaan ekstrak daun sirih (Piper betle linn.) pada perendaman telur tetas itik Mojosari terhadap daya tetas dan mortalitas embrio. Jurnal IImu-IImu Peternakan 25 (1): 16-23.

Neto Bandeira G, C Augusto Gomes da Camara, M Martins de Moraes, R.Barros, S Muhammad, Y.Akhtar. 2013. Insecticidal activity of Muntingia calabura extracts against larvae and pupae of diamondback, Plutella xylostella (Lepidoptera, Plutellidae). Journal of King Saud University Science. 25(1). pp. 83-89. doi: 10.1016/j.jksus.2012.08.002.

Setiadi P. 2000. Pengaruh indeks bentuk telur terhadap persentase kematian embrio, gagal tetas, dan DOD cacat pada telur itik Tegal yang di seleksi. Anim Prod. 2(1):25-32.

Shahein E.H.A dan Sedeek Eman K. 2014. Role of spraying hatching eggs with natural disinfectants on hatching characteristics and eggshell bacterial counts. Egypt. Poult. Sci. Vol (34) (I): (211-228).

Sinabutar, M. 2009. Pengaruh Frekuensi Inseminasi Buatan Terhadap Daya Tetas Telur Itik Lokal yang Di Inseminasi Buatan dengan Semen Entok. Fakultas Pertanian. Universitas Sumatra Utara. Medan.

Zeweil, H.S, Rizk, R.E, Bekhet, G.M, Ahmed, M.R. 2015. Comparing the 
effectiveness of egg disinfectants against bacteria and mitotic indices of developing chick embryos. The Journal of Basic \& Applied Zoology. v.70, p.1-15. DOI: 10.1016/j. jobaz.2014.12.005 